\title{
The French Musical: Swing and Big Bands in the Cinema of the 40s and 50s
}

The musical is generally considered to be a major Hollywood genre in ways that, with the exception of Bollywood, it is not for other national cinemas. Although the Hollywood musical has been in decline since the 1960s, it appears to have had a resurgence around the turn of the millennium, with films such as Moulin Rouge (Baz Luhrmann, 2001), Chicago (Rob Marshall, 2002), and the Bollywood crossover Bride and Prejudice (Gurinder Chadha, 2004). ${ }^{1}$ That resurgence is also evident in the French musical, which has become an increasingly visible feature of French cinema since the 1990s, a little before the Hollywood resurgence, with films by Alain Resnais, François Ozon, Christophe Honoré, and Olivier Ducastel and Jacques Martineau amongst others. ${ }^{2}$

Most film histories do not recognize the musical as a typically French genre; indeed, the foremost French writer on sound and music in the cinema, Michel Chion, lamented the fact in 2002 that there is as yet no major work on the genre, something that remains true a decade later. ${ }^{3}$ Directors who made musicals, such as René Clair and Jacques Demy, are more often than not seen as auteurs rather than as contributors to a specific genre; even books devoted to music in the French cinema focus on individuals -composers, singers, directors-rather than addressing the musical as a genre. ${ }^{4}$ This is all the more curious given that musicals were as popular in the French cinema during the 1940s and 1950s as they were in Hollywood. The films of Tino Rossi, Luis Mariano, and Ray Ventura were amongst the best-selling films of the 1935-1955 period.

This article is part of a larger project that aims to stake a claim for the French musical as a national genre. The article will focus on the films of Ray Ventura and his circle, which echo the swing and Big Band films of Hollywood, but which have a distinctively French flavour, given their links with French vaudeville and music hall traditions. The article is in three sections. The first will place the Big Band musical within the broad landscape of music in the French cinema, and outline the codes of the sub-genre 5 in its French context, with a particular emphasis on the interaction between narrative and musical numbers. The second will show how the Big Band films demonstrate a tension between the old and the new, the romantic couple and the community, and between France and the USA. The final section will focus on a single case study, the best-selling French film of 1950, Nous irons à Paris/We Will All Go to Paris.

\footnotetext{
${ }^{1}$ See Steven Cohan, 'Introduction: How Do You Solve a Problem Like the Film Musical?', in Steven Cohan (ed.), The Sound of Musicals (London: BFI, 2010), pp. 1-5; he reports that the genre's comeback is generally seen as 'an improbable possibility' (p. 5).

${ }^{2}$ On connaît la chanson/Same Old Song (Alain Resnais, 1997), Jeanne et le garçon formidable/Jeanne and the Perfect Guy (Olivier Ducastel et Jacques Martineau, 1998), 8 femmes/8 Women (François Ozon, 2002), Pas sur la bouche/Not on the Lips (Alain Resnais, 2003), Crustacés et coquillages/Cockles and Muscles (Olivier Ducastel et Jacques Martineau, 2005), Les Chansons d'amour/Love Songs (Christophe Honoré 2007). I have used the English-language titles from the Internet Movie Database; where these do not exist, I have given a literal translation.

${ }^{3}$ Michel Chion, La Comédie musicale (Paris: Cahiers du cinéma, 2002), p. 94.

${ }^{4}$ For example Alain Lacombe and François Porcile, Les Musiques du cinéma français (Paris: Bordas, 1995) and Michel Chion, La Musique au cinéma (Paris: Fayard, 1995).

${ }^{5}$ For the distinction between sub-genre and cycle, see Jane Feuer, 'The International Art Musical:

Defining and Periodizing the Post-1980s Musical', in Cohan (ed.), The Sound of Musicals, pp. 54-55.
} 
The 1930s and the coming of sound changed the performance landscape in France as it did in Hollywood. Three types of musical performance on screen became established by the end of the decade.

In the first group are those films in which individual singers, generally from the music-hall tradition, perform songs. ${ }^{6}$ Within this first group it is worth identifying a particular sub-group, the so-called 'realist' singers, who have attracted more sustained scholarly analysis than those previously listed. ${ }^{7}$ In this first group of films, the performer generally sings a small number of songs, often no more than three, and sometimes only one. For that reason, the films in this first group do not constitute a musical film genre, not least because the songs are incidental to the narrative. Seeing a singer perform on screen would clearly have been attractive to audiences, but was not the film's focus. There are films in which there is more than the occasional song, and those songs are less incidental to the narrative. This is the case with the revue film that focuses on a show. ${ }^{8}$ It is also, arguably, the case with Charles Trenet. Although Trenet published more than 560 songs, he only appeared in a handful of films. The best-known were La Route enchantée/The Enchanted Road (Pierre Caron, 1938) and Romance de Paris/Paris Romance (Jean Boyer, 1941), in both of which he plays a singer. He was influential, however, for introducing American jazz styles during the early 1930s as part of the duo 'Charles et Johnny' (Charles Trenet and Johnny Hess); their songs combined popular French forms with jazz inflections. They could be said to have 'jazzified' French chanson, while the Big Band films that are the focus of this article Gallicized jazz. But although there were films in which songs are less incidental to the narrative, there are too few of them to constitute a clear genre.

The second group of films with musical performances --the operetta films-are much more obviously a genre. Within this genre, there are three distinct subgenres: adaptations of nineteenth-century stage operettas, the Marseille operetta film, and what might be called the crooner spectacular, starting with Tino Rossi in the 1940s, and then Luis Mariano in the 1950s. Several nineteenth-century stage operettas were adapted for the screen both during the silent period and even more so after the arrival of sound. ${ }^{9}$ As is the case with films where there are more than a couple of songs, there are too few operetta adaptations to constitute a strong sub-genre. This was not the case, however, with the more local, and very popular Marseille operetta film. Although the narrative does not always focus on a singer, typically there are half a dozen musical numbers, rather than the one or two associated with realist singers. This sub-genre was dominated by the singer/librettist Henri Alibert and his composer father-in-law Vincent Scotto. ${ }^{10}$ The third sub-genre is the spectacular operetta films of Tino Rossi and Luis Mariano. Rossi's major successes were during the 1940s when his films attracted between three to four million spectators. Mariano's successes were during the 1950s, his more successful films attracting over five million spectators:

\footnotetext{
${ }^{6}$ See Lacombe and Porcile, Les Musiques du cinéma français, pp. 65-71.

${ }^{7}$ For an overview see Lacombe and Porcile, Les Musiques du cinéma français, pp. 67-68. For detailed analysis, see Ginette Vincendeau, 'The Mise-en scène of Suffering: French Chanteuses réalistes', New Formations, no. 3 (1987), pp. 107-28, and Kelley Conway, Chanteuse in the City: The Realist Singer in French Film (Berkeley/Los Angeles/London: University of California Press, 2004), pp. 84-129.

${ }^{8}$ For example Zouzou (Marc Allégret, 1934) starring Josephine Baker, and Paris-Béguin with Gabin (Augusto Genina, 1931); see Conway, Chanteuse in the City, pp. 139-48.

${ }^{9}$ Claude Autant-Lara adapted Reynaldo Hahn's 1923 operetta Ciboulette in 1936; Hervé's 1883 operetta Mam'zelle Nitouche was adapted by both Marc Allégret in 1931 (starring Raimu) and his brother Yves in 1954 (starring Fernandel).

${ }^{10}$ They had a series of successful films of stage operettas during the 1930s; see René Gieure, 'Chanson et cinéma. IX. Opérette, comédie musicale, music-hall’, Image et Son, no. 128, pp. 23-26 (p. 23).
} 
Andalousie/Andalusia (Robert Vernay, 1951), originally a stage operetta from 1947, was the best-selling French film of 1951 with 5.7 million spectators, while Violettes impériales/Imperial Violets (Richard Pottier, 1952) was the second best-selling French film of the year with 8.1 million spectators.

The Big Band films constitute the third musical genre and are the focus of this article. They began appearing in the late 1930s, and remained an important part of French film culture during the 1940s and early 1950s. They are distinct from the other two types of films with musical performances in that, like Trenet before them, ${ }^{11}$ they engage more obviously with American-style jazz, and as a result raise key questions about the relationship between French and US culture in France. Like the films of Mariano and Rossi, the big band films are structured around the performers and around the performances themselves, with sub-plots taking a secondary role. Preeminent amongst these films are those of Ray Ventura and his orchestra, known as 'Ray Ventura et ses Collégiens', who played on stage and on radio throughout the 1930s and 1940s, and whose songs were incorporated in their films.

Two recent books on French jazz confirm the importance of Ventura in the 1930s. Ventura is 'the most famous pre-war conductor of the variety style', ${ }^{12}$ and he and his orchestra are 'the most popular French orchestra [...]. Ray Ventura et ses Collégiens had taken to its peak the genre called "on-stage jazz", by which is meant orchestras taken out of the pit onto the stage, and capable of interpreting jazz, songs and comic turns'. ${ }^{13}$ They regularly performed in the major Paris venues during the 1930s. ${ }^{14}$ After a concert in Bobino in 1932, the newspaper Candide called them 'the first high-class French jazz orchestra', considering that they were 'as good as any Anglo-Saxon jazz orchestra', ${ }^{15}$ by which was meant both American and British bands. The same newspaper followed up on a variety performance at l'Alhambra later the same year, saying that "the great merit of the "Venturiens" is their continual renewal of a well-known repertoire', ${ }^{16}$ and Le Journal admired 'an excellent French jazz, a joyous jazz'. ${ }^{17}$ Ventura's importance for French jazz is difficult to overestimate, partly because he created jazz versions of well-known traditional French songs, such as 'Sur le pont d'Avignon', or 'Frère Jacques', combining modern jazz with nostalgia, as Jeffrey H. Jackson points out. ${ }^{18}$

This was the period of the Big Bands more generally. During the 1930s there was Fred Adison and his orchestra (a Frenchman despite his name), then the orchestras of Raymond Legrand and Jacques Hélian during World War Two, and later Aimé Barelli. American and British orchestras performed regularly in Paris. Jack Hylton, for example, an Englishman, was proclaimed 'king of jazz' by the French, and awarded the Legion of Honour in $1932 .{ }^{19}$ Ventura is a special case, not just because he Gallicized jazz, but for three further reasons.

\footnotetext{
${ }^{11}$ See Larry Portis, French Frenzies: A Social History of Pop Music in France (LaVergne, Tennessee: Lightning Source, 2004) pp. 70-73.

12 Gérard Régnier, Jazz et société sous l'Occupation (Paris: L'Harmattan, 2009), p. 54.

${ }^{13}$ Annie Legrand, Charles Delaunay et le jazz en France dans les années 30 et 40 (Paris: Editions du Layeur Legrand, 2009), p. 127.

${ }^{14}$ For example, Bobino (1932, 1933, 1935, 1936), L'Empire (1931, 1932), L'Alhambra (1932, 1936).

${ }^{15}$ Candide, 18 February 1932, no pagination available.

${ }^{16}$ Candide, 20 October 1932, no pagination available.

${ }^{17}$ Le Journal, 11 October 1932, no pagination available.

18 Jeffrey H. Jackson, 'Making Jazz French: The Reception of Jazz Music in Paris, 1927-1934', French Historical Studies, vol. 25, no. 1, (2002), pp. 149-70 (p. 160).

${ }^{19}$ Deborah Mawer, '"Parisomania"? Jack Hylton and the French Connection', Journal of the Royal Musical Association, vol. 133, no. 2 (2008), pp. 270-317.
} 
First, Hélian and Legrand were members of his orchestra before forming their own, the former in 1937, the latter in 1940, their work taking its cue from his. Second, and more importantly, Ventura was a film producer; he established his own production company, Hoche, in 1947, which produced some fifteen films, including the film which launched the screen career of the rock n roll star Johnny Hallyday, D'où viens-tu, Johnny?/Where Are You From, Johnny? (Noël Howard, 1964). Third, he starred along with his orchestra in eight films, more than the other bandleaders. Adison and his orchestra only appeared in one minor film, A nous deux, Madame la vie/It's Between Us, Mistress Life (René Guissart and Yves Mirande, 1937). Legrand also appeared in only one film, Mademoiselle Swing (Richard Pottier, 1941), although this one had a significant impact because it represented a generational shift towards a very specific youth culture, that of the 'Zazous' ${ }^{20}$ Hélian and his orchestra appeared in six. One of these, Pigalle-Saint-Germain-des-Prés (André Berthomieu, 1950), was produced by Hoche, and Ventura was one of the co-writers. Aimé Barelli also appeared in a number of films, amongst them La Petite chocolatière/The Chocolate Girl (André Berthomieu, 1949) and Les Joyeux pélerins/The Gay Pilgrims (Alfred Pasquali, 1951). He himself was not a member of Ventura's orchestra; however, we find one of Ventura's Collégiens, Coco Aslan, in the second film, and a number of Ventura's regular actors in the first: the Fernandel look-alike Max Elloy, and Henri Genès, with his pronounced Mediterranean accent. Moreover, the music for both of these films was composed by Ventura's regular collaborators, composer Paul Misraki, and lyricist André Hornez. When we add to this the fact that Raymond Legrand is the father of the well-known film composer Michel Legrand, and that Hélian was his uncle, it becomes clear that this group of performers and composers were an important and very visible feature of French cinema in the 1940-1950 period; it is all the more surprising therefore that no scholarly work has been devoted to their films.

Ventura's and his orchestra starred in eight films. ${ }^{21}$ To these we should add Pigalle-Saint-Germain-des-Prés. Although the film stars Hélian and his orchestra (as well as Jeanne Moreau in her third film), it was produced and co-written by Ventura. Moreover, in his short appraisal of the French film musical Chion couples it with Ventura's Tourbillon de Paris, as good examples of the genre. ${ }^{22}$

Ventura's first film was a film version of his very popular song 'Tout va très bien Madame la Marquise', which had sold 600,000 records in 1935. The orchestra's role was small, as was the case with Aventure à Paris, an adaptation of Henry Falk's stage-play Le Rabatteur (The Beater), with Arletty and Jules Berry; the orchestra did not even feature on the film poster. That changed with Feux de joie in 1938; the orchestra became the star of the film, the romantic sub-plot being relegated to second place. In the brief synopses that follow, the focus is principally on the role of musicians. In Feux de joie a group of Parisian musicians cycle down to the Côte d'Azur to set up a hotel after their military service. They attract custom, and therefore the wrath of a competitor, with their musical shows. In Tourbillon de Paris, the

\footnotetext{
${ }^{20}$ On the 'zazou film', see chapter 7 of Noël Burch and Geneviève Sellier La Drôle de guerre des sexes du cinéma français (1930-1956) (Paris: Nathan, 1996), pp. 133-41 (p. 136 on Mademoiselle Swing).

${ }^{21}$ Tout va très bien Madame la Marquise/Everything is Alright, Madame la Marquise (Henry Wulschleger, 1936), Aventure à Paris/Adventure in Paris (Marc Allégret, 1936), Feux de joie/Bonfires (Jacques Houssin, 1939), Tourbillon de Paris/Whirlwind of Paris (Henri Diamant-Berger, 1939; producer Ray Ventura), Mademoiselle s'amuse/Mademoiselle Has Fun (Jean Boyer, 1948), Nous irons à Paris/We Will All Go to Paris (Jean Boyer, 1950; producer Ray Ventura), Nous irons à MonteCarlo/Baby Beats the Band (Jean Boyer, 1951), Femmes de Paris/Women of Paris (Jean Boyer, 1953; producer/co-writer Ray Ventura).

${ }^{22}$ Chion, Comédie musicale, p. 63.
} 
journey is the other way round: the Collégiens improbably play the role of schoolchildren, this being partially legitimated by their orchestra's name. They have come to Paris to sit their exams, and earn their living by giving shows.

Tourbillon de Paris was released in 1939. At the outbreak of the Second World War, Ventura, who was Jewish, left for South America with his orchestra, their musical and film career in France taking off once more on their return in 1947, when Ventura changed many of the musicians, as well as setting up his production company. Christine, in Mademoiselle s'amuse, is the spoilt daughter of a rich American. She loves jazz, and manages to persuade her father to pay for Ventura and his orchestra to follow her everywhere she goes; the musicians end up deserting her, and as a result of trying to persuade them back, she discovers the realities behind their lives as well as learning a lesson in humility. We stay in Paris for Pigalle-SaintGermain-des-Prés. The plot of the earlier Feux de joie revolved around two rival hotels; in this film, the plot revolves around two different musical venues, as is indicated by the title. The first is in the insalubrious Pigalle district, and is run by gangsters. The musicians they employ leave to set up 'existentialist' club in the university area of Saint-Germain-des-Prés. The same year, Ventura released the bestselling Nous irons à Paris, in which Henri Genès (who plays the entrepreneurial barman of Pigalle-Saint-Germain-des-Prés), a former Resistance fighter unhappy with the job he has in state radio, decides to set up a clandestine radio with his friends. They are supported by Ventura and his orchestra. The team, as is indicated by the title, travel from the country to the capital with state radio and police in hot pursuit; but 'Radio X' has become such a popular phenomenon that they are welcomed as celebrities. In the film that tried to repeat the winning formula of Nous irons à Paris, Nous irons à Monte-Carlo, the journey is once more in the opposite direction. The orchestra goes to Monte-Carlo for a festival, with a baby that Honorin (Max Elloy) believes to be his grandson; but the boy is in fact the son of warring American film stars, each of whom wants the child. There is considerable confusion as to the child's paternity, Ventura himself being accused at one point of being the child's father. The film starred Audrey Hepburn as the mother of the child, prior to her breakthrough two years later in Roman Holiday (William Wyler, 1953); Boyer made an Englishlanguage version at the same time as the French version, entitled Monte Carlo Baby, and this was released in the USA two months after Roman Holiday.

The six central films are remarkably consistent in their foregrounding of the orchestra and its music, as they are in their codes. It was a formula that remained stable until the last film, Femmes de Paris. This film shades back regressively into the variety show format, and is dominated not by the orchestra but by one of the great stars of the period, Michel Simon. He plays the role of an astronomer phoned by an unknown woman threatening suicide in a nightclub. He tries to head off the suicide, which is little more than a pretext for a sequence of musical numbers. Ventura's orchestra is used for only one of the sketches, sharing the stage with other popular music hall or variety stars of the time, for example the comedian Robert Lamoureux, and the singer Patachou.

The six central films, on which we will focus, are backstage musicals; they are about the eventual success of Ventura's orchestra on stage. Even when the ostensible narrative goal is establishing a successful hotel, as is the case in Feux de joie, success is predicated on a successful show. The formula appears to change in Nous irons à Monte-Carlo, but this is only in appearance. The orchestra is in Monte-Carlo for the jazz festival, and the events surrounding the baby prevent them from performing as expected. While the majority of the orchestra is in pursuit of the baby and his 
kidnapper, Ventura and his quintet mime to the music played on a record behind the scenes, with orchestra director Julien (Henri Genès) -who had told us at the beginning of the film that he 'plays a variety of instruments, in short I'm a man-orchestra'doing a comic turn as he rushes from one instrument to the next.

While the orchestra is the main protagonist in these films, there are nonetheless several subsidiary protagonists: the young romantic couple, generally formed by the main singer of the orchestra and a woman who is at first external to the orchestra, but is gradually accepted as part of the team by virtue of her affair with the singer. This is the case for Micheline (Micheline Cheirel) in Feux de joie, who gets together with Roland (René Lefèvre), and for Pâquerette (Jeanne Moreau) in PigalleSaint-Germain-des-Prés, who gets together with Jean-Pierre (Gabriel Cattand), as it is for Christine (Gisèle Pascal) in Mademoiselle s'amuse, who separates from Jacques (Bernard Lancret), only to get back together with him at the end of the film. He is not part of the orchestra, but he nonetheless sings.

Alongside the romantic couple are the two comic protagonists: first a largerthan-life member of the orchestra, and second the father of the woman, who, like his daughter, is eventually won over by the music and the musicians. In the case of the first internal comic character, it is Coco Aslan in Feux de joie and Tourbillon de Paris, followed by Henri Genès (Pigalle-Saint-Germain-des-Prés, Nous irons à Paris, Nous irons à Monte-Carlo), and Max Elloy (Mademoiselle s'amuse, Nous irons à Paris, Nous irons à Monte-Carlo). In the case of the second, external comic character, it is the director of the college in Tourbillon de Paris, but in subsequent films it is always the father of the female romantic character, and in two of the films he is a widower (Mademoiselle s'amuse, Nous irons à Paris).

Consistency of narrative form and consistency of character formations are paralleled by a second systematic characteristic: consistency in the musical numbers. There are generally no more than six musical numbers in these films, arguably one of the more distinctive features of the film musical. ${ }^{23}$ These are systematically distributed across the film. At the beginning of the film during the credits there is always a version without words of the main song of the film. The first full musical number occurs approximately ten minutes into the film, the second between 15-20 minutes (with the exception of Pigalle, in which it occurs immediately after the credits). The final number is a medley of the preceding numbers, and signals the end of the film (with the exception of Mademoiselle s'amuse). The reason it is worth dwelling on these characteristics is that they are different in other film musical subgenres. For example, a sample of tenor Tino Rossi's equally codified films gives a maximum of eight musical numbers rather than six; the number heard during the credits is not always constituted as a medley; and the first number can occur anywhere between 15 and 35 minutes. $^{24}$

A third systematic characteristic is the nature of the musical numbers' music and lyrics, and the performance of the music and lyrics. The music is, as might be expected from a Big Band, brass heavy, mostly swing, with frequent samba rhythms; music and lyrics are boisterous, a 'joyous jazz' as quoted above. Although there is a front singer, generally the internal comic character or the romantic lead mentioned above, the musicians frequently take turns to sing, this occurring more in the film versions than in the recorded versions of the songs. The songs fall broadly into two

\footnotetext{
${ }^{23}$ See Feuer, 'The International Art Musical', p. 54.

${ }^{24}$ The sample includes Lumières de Paris/Lights of Paris (Richard Pottier, 1938), Marinella (Pierre Caron, 1936), Naples au baiser de feu/The Kiss of Fire (Augusto Genina, 1937), and Le Soleil a toujours raison/The Sun Is Always Right (Pierre Billon, 1943).
} 
categories: the song that tells a story, and the song that uses a series of vignettes to illustrate a theme. In both cases, Hornez's lyrics systematically use puns, bathos and innuendo in inventive ways, and the singers typically use exaggerated and frequently camp singing styles, gestures and facial expressions as part of their performance.

An example of the story song is the samba 'Maria de Bahia' published in 1946 and integrated in Mademoiselle s'amuse two years later. It tells the story of Maria, the free and easy belle of the town, who becomes a film actress and returns to Bahia, presumably abused and rejected, where she marries a nerd and remains forever faithful. At the beginning of the song, which describes her coquettish ways, Henri Salvador campily simpers as he mimics her seductions. There is innuendo: 'Quand on l'avait trop embrassée/Elle allait se confesser et puis elle recommençait' (When she had been kissed too much/She'd go to confession and then start all over again'). There are witty puns, such as the following play on 'tamtam': 'Le tamtam disait t'as bien raison de t'am t'amuser' (The tamtam said you're right to have fun). There are, finally, in the purely formal sense, some magnificent internal rhymes with comic emphasis, such as the repeated $-\mathrm{a},-(\mathrm{r}) \mathrm{ia}$ and -rio in the following stanza; the rhymes are heavily accentuated by the music, the singing, and the gestures of the band:

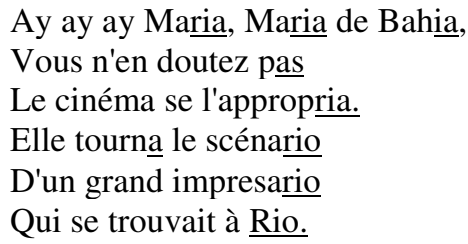

\author{
Ay ay ay Maria, Maria of Bahia, \\ You won't be surprised to hear \\ The cinema snatched her up. \\ She starred in the film \\ Of a famous producer \\ From Rio.
}

An example of the sketch song exemplifying a theme is 'Tout mais pas ça' (Anything but that) from Nous irons à Monte-Carlo. The theme is what the future career of the baby at the centre of the story might turn out to be; Henri Genès proposes descriptions of potential career choices, which members of the band try to guess. Verbal dexterity yields by the end of the number to energetic gestures as the musicians illustrate the careers; indeed, towards the end of the number Henri Genès does a rapid sequence of comic charades, almost as if the music and lyrics' energy had caused the number to explode into highly visual acting outs:

Moi je connais un métier magnifique,

Je dirais même un apostolat.

En plus de ça, c'est honorifique.

J'ai trouvé: marchand de nougat!

Mais non, c'est le métier de celui qui protège

Les honnêtes gens contre les margoulins,

Et qui de plus, comment dirai-je,

Soutient la veuve et défend l'orphelin.

Eureka! Avocat! Avocat! Pourquoi pas?

Avocat? Avocat? Non, tout mais pas ça,

Tout tout tout mais pas ça!

Un avocat c'est noir et c'est triste,

Moi je préfèrerais général.

Tout mais pas ça,

Tout tout tout mais pas ça!

Moi je propose plutôt dentiste, hein.

Ah non, ça fait trop mal.
I know of a magnificent job,

Why it's a sacred mission.

Moreover it's honorary.

I know: nougat merchant!

No no, it's the job of he who protects Honest folk from swindlers,

And what's more, how can I put this,

Stands up for widows and defends orphans.

Eureka! Lawyer! Lawyer! And why not?

Lawyer! Lawyer! Anything but that,

Anything anything anything but that!

A lawyer's black and sad,

I would prefer a general.

Anything but that,

Anything anything anything but that!

I propose dentist then.

Oh no, it hurts too much. 
Il sera médecin. C'est malsain.

Il sera poète. Pas si bête.

Commis voyageur ou plongeur.

Ce serait bien plus battant d'en faire un acrobate.

Non, tout mais pas ça,

Tout tout tout mais pas ça!

Vous voyez bien que c'est un artiste,

Il est fait pour chanter l'opéra,

Il vous épatera en chantant la Tosca.

Tout mais surtout pas ça!

$[\ldots]$

L'amour c'est la plus belle des richesses,

Alors il faut en faire un pasha.

Il aura comme cela des tas de femmes sur les bras.

Tout mais surtout pas sha!

Cordonnier?

Tout mais surtout pas!

Couturier? Cuisinier? Gangster??

Eh bien Messieurs, si l'on en faisait tout

simplement un musicien?

Tout mais pas ça,

Tout tout tout mais pas ça!

C'est le dernier métier sur la terre.

Mais qu'est-ce qu'il vous a fait ce bébé-là?

C'est les travaux forcés avec Ray Ventura.

Tout tout tout tout tout, mais surtout mais pas ça!
He'll be a doctor. It's unhealthy.

He'll be a poet. Not so bad.

Salesman or diver.

It would be much better if he were an acrobat. No, anything but that,

Anything anything anything but that!

Can't you see that he's an artist?

He's made to sing opera,

He'll wow you by singing Tosca.

Anything, anything but that!

$[\ldots]$

Love is one of life's great riches, So let's make him a pacha.

He'll have loads of women on his hands.

Anything but especially not that!

Cobbler?

Anything but that,

Fashion designer? Cook? Gangster?

Well, sirs, what if we made him simply a musician?

Anything but that,

Anything anything anything but that!

It's the worst job on earth.

Whatever did that poor baby do to you?

It's hard labour with Ray Ventura.

Anything anything anything anything anything but that!

There are a number of points to note in this song: first, there is bathetic disintegration as respected professions (lawyer, dentist, doctor) give way to considerably less statusdriven jobs (salesman, diver); second, the constant rhyming of short statements with comical emphasis (e.g. médecin/malsain; poète/bête; voyageur/plongeur; riche/fiche); third, the sly campiness that permeates the number. Genès pretends to be a ballerina at one point, something the band immediately rejects; he falls into Max Elloy's arms as we are told he could be a pasha with 'loads of women' falling into his arms. That stanza is double-edged, given that the expression 'sur les bras' can in this context be taken to mean that he would have many women on his arms, as well as its more idiomatic sense of being burdened with something. It is hardly surprising then that the chorus comes in with an emphatic variant on the normal chorus: 'Tout mais surtout pas sha!' (Anything but especially not that!), a variant that draws attention to itself with the pun on pacha ('pas sha' instead of 'pas ça'), the concept of heterosexual relations being in the process fundamentally queered (anything but women). Finally, the number ends, as several others in these films do, with a self-reflexive dig at Ventura himself. 


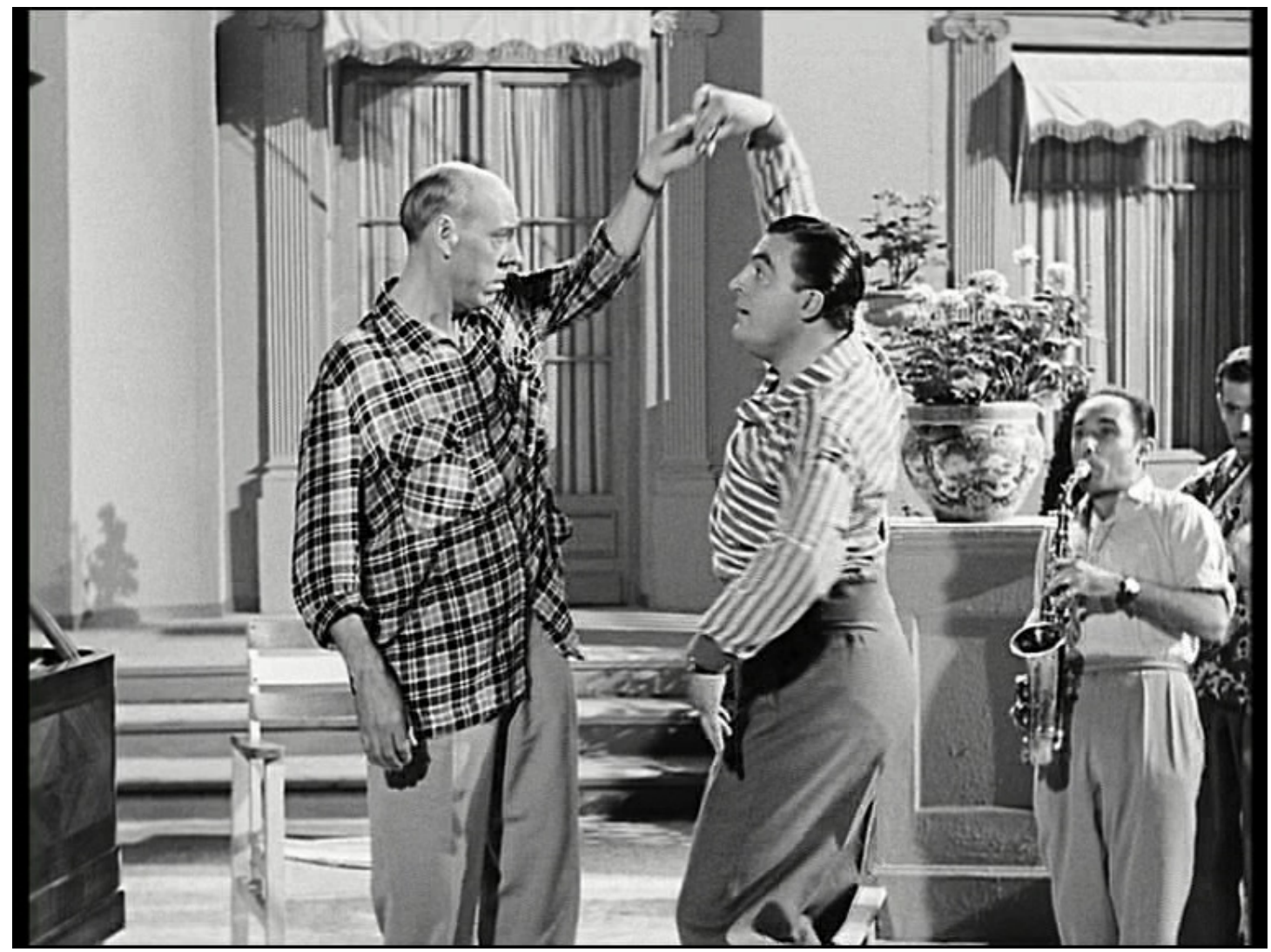

Figure 1: Genès's charade as a ballerina in Nous irons à Monte-Carlo (René Château Vidéo).

A third characteristic of the musical numbers in the Big Band films is repetition. The musicians rehearse as they prepare the show, in such a way that we hear extracts of numbers several times over; and the final medley re-repeats those numbers. The finale of Feux de joie, for example, picks up four of the five numbers of the film: 'Qu'est-ce qu'on attend pour être heureux' (Why Are We Waiting to be Happy?), 'Près de vous dans le soir' (Near to You in the Evening), 'Comme tout le monde' (Like Everyone), 'Y'a des jours où toutes les femmes sont jolies' (There are Days When All Women Are Pretty). In Mademoiselle s'amuse, there is an extraordinary criss-crossing of two numbers: 'Sans vous' (Without You) occurs in the tenth, twenty-fifth and one-hundred and fifth minutes; 'Maria de Bahia' (Maria From Bahia) meanwhile occurs in the twentieth and thirty-fifth minutes; and the two numbers come together in the final medley.

Repetition does not only occur within the films, but from one film to another. 'La Marche des copains' (The March of the Buddies) is heard at the start of Nous irons à Paris, and then again at the start of the following film, Nous irons à MonteCarlo. A film is just as likely to repeat numbers from Ventura's general repertoire. 'Maria de Bahia' was published in November 1946, while the film in which it occurs, Mademoiselle s'amuse, was released in February 1948. In the same film we hear 'Tout va très bien, madame la marquise' (published in May 1935) and 'Ça vaut mieux que d'attraper la scarlatine' (It's Better than Catching Scarlet Fever, published October 1936), snatches of these two songs occurring in the medley 35 minutes into the film.

Repetition has several functions. First, given that most of the songs were not new but reprises from the Ventura repertoire, they have a nostalgic function, 
frequently referring the listener back to the pre-war period; although as we will see below, this function is held in tension with the new, post-war France. Second, the constant criss-crossing of the repertoire in a body of films, combined with the other formal codes discussed above, helps to cement the genre. Third, repetition across media (records, radio, stage, cinema) creates what we might call an intermedial community $^{25}$ of listeners and viewers, which functions as a proxy for national community; indeed, the fact that the music is produced by what comes across as an extended family serves to emphasize this function.

A final characteristic of these films is the frequent use of the animated sketch. This is a number in which the musicians illustrate the words of the song in comic fashion, generally using disguises (rather than just acting out as we saw in 'Tout mais pas ça'), and often introducing substantial props and decor. This feature is interesting because it creates a space of fantasy that undermines diegetic spatial conventions. It is perfectly clear to us that the musicians would not have had time to change their costumes in the film's diegetic temporality, and even less the time to erect the often complex sets from one stanza of the song to another. This type of musical number becomes an interlude, a ludic and carnavalesque interruption of the diegesis. It is as if the film were about to explode, given that the musical rhythms in the numbers are generally very fast, and that the elements of costume and decor become increasingly complex, and therefore unreal, as the number progresses.

A good example is the number 'Comme tout le monde' in Feux de joie, a song that confronts dream and reality --what one does and what one would like to do-- so as to affirm the importance of the everyday (doing things, as the title says, just like everybody else). During the first stanza, a variety of singers sing to the camera; however, in the second stanza Jimmy Gaillard puts a military cap on his head, as he sings 'you dream of being a general'. Then he takes a cowboy hat and gun as he sings 'or a cowboy in the Transvaal', and then a boater as he sings, with a Maurice Chevalier accent, 'or a worldwide star'. There is nothing particularly odd in the use of these props; a hat appears to illustrate each line. But suddenly, for the fourth line, 'and in the end you're just a pencil-pusher', we see and hear a chorus of desk-clerks with traditional cuffs and bonnets. This introduces a stanza devoted to clothing, where the singers are more and more ridiculed; we see them in pyjamas, long-johns, socksuspenders, finishing on 'we shave every morning', the chorus lined up like Busby Berkeley dancers. And in the last stanza, which focuses on the exotic locations where a man might take a woman on a romantic holiday, a number of countries are evoked not only through costumes, but by extensive decor reminiscent of the music hall. We see a gondola passing across the back of the stage as we hear the words 'you speak to her of Venice', men in top-hats and drinking whisky as they sing 'For He's a Jolly Good Fellow' ('or the banks of the Thames'), pretend-Chinese ('or Saigon'); but we finish bathetically in a very traditional bal dansant (popular dancehall): 'and in the end you take her to Meudon'.

This type of animated sketch occurs in three other films of the corpus: Tourbillon de Paris, Nous irons à Paris, Nous irons à Monte-Carlo, and again in Femmes de Paris. In the case of Nous irons à Monte-Carlo, the same routine is used of reviewing national stereotypes, in theatrical decors. We see kilted Scotsmen dancing, Genès as a toreador seducing Philippe Lemaire dressed as a woman in a Spanish setting; yodelling Swiss; Russians complaining about the snow; and

\footnotetext{
${ }^{25}$ See Freda Chappl and Chiel Kattenbelt (eds), Intermediality in Theatre and Performance (Amsterdam: Rodopi, 2007) for a recent theoretical discussion of the concept of intermediality; they do not cover radio, however, nor do they address the concept of an 'intermedial community'.
} 
Neapolitans arguing. In Tourbillon de Paris, the number entitled 'J'ai besoin de vous' (I Need You) reviews a range of professions in a space and a temporality that are more or less diegetic, in the sense that the musicians are already dressed in national costumes at the start of the number. But in the second animated sketch, 'Vivement dimanche' (Finally Sunday), which takes place in the Bourget airport at the end of the film, various Sunday activities are illustrated with interpolated studio sets consisting of cartoon decors: musicians comically disguised as ordinary families stroll along studio set streets, ride bicycles, paddle in cardboard canoes, and finally camp out in woods painted on wooden backdrops.

Although the more technical aspects of musical numbers might not seem to be as ideologically driven as narrative situations, they convey very specific meanings. The systematic and the repetitive, and any sense of comfort that these might generate, are undermined by the animated sketch. The orchestra's stage set is gradually invaded by fantasy elements of decor that fissure any sense of realist space. And as the details of the narratives and musical numbers may well have suggested, the persistent comic elements involving misunderstandings, cross-dressing, as well as the often extraordinary puns in Hornez's lyrics, which draw us away from narrative to an energetic performance space, all function to destabilize the diegesis. The Bakhtinian carnavalesque $^{26}$ is clearly a useful way to describe this effect, and it would be tempting to leave it at that. The Big Band musical in this reading would be, like much popular entertainment, no more than a turning of the world upside down, of which the animated sketch is the structural exemplification in its fantastical undermining of the realist aesthetic. To reprise Rick Altman's view of the Hollywood musical, 'the music creates a utopian space in which all singers and dancers achieve a unity unimaginable in the now superseded world of temporal, psychological causality'. ${ }^{27}$ There is arguably much more to be said about this utopian space.

These films manifest ideological tensions between the old and the new, rather than simply the Bakhtinian tension between high and low culture. Both in their opposition between the young and the old (the latter incarnated by the comical father), and their opposition between jazz and so-called classical music (the first associated with the USA, and the second with French high culture), these films constantly return to the fundamental opposition between old, pre-war France and post-war France in transition to something new, something younger and more modern. Three good examples of this opposition are the popular view of existentialism, American references, and different types of music.

Existentialism in post-war Paris was not just an intellectual movement, made popular by Jean-Paul Sartre and Albert Camus, but a bohemian and oppositional way of life for students and intellectuals. Focused on the cafes and nightclubs of the Left Bank around Saint-Germain-des-Prés, and analogous to the Beats in the USA, this phenomenon was very much linked to jazz and poetry, as much as to philosophy. ${ }^{28}$ The title Pigalle-Saint-Germain-des-Prés is in itself significant, as it contrasts two very different parts of Paris and two different styles of dance music. The film contrasts a large cabaret in the Pigalle area belonging to gangsters, and which is not doing well -flower girl Pâquerette (Jeanne Moreau) is not able to sell any flowers-

\footnotetext{
${ }^{26}$ See Mikhail Bakhtin, Rabelais and His World, trans. Helene Iswolsky (Cambridge, Mass.: M.I.T. Press, 1968).

${ }^{27}$ Rick Altman, The American Film Musical (London: BFI, 1989), p. 69.

${ }^{28}$ For a recent account, see ch. 6 'The Left Bank' in Rosemary Wakeman, The Heroic City: Paris, 1945-1958 (University of Chicago Press, 2009), pp. 241-88.
} 
with the cellar of a cafe (a 'cave') in Saint-Germain, where young people gather together and listen enthusiastically as Pâquerette reads a (bad) poem by her lover, or frenetically dance be-bop and swing.

But the film shows an underlying anxiety about existentialism; it is consistently mocked in its superficial manifestations. So, for example, when the new club set up by the friends begins to attract the crowds, Genès says: 'Existentialism isn't a cellar, it's a goldmine'. When the police close the cellar after a battle there with the gangsters, Jean-Pierre complains, saying that 'Existentialism has the right to exist'. Hornez's lyrics for the main song of the film uses contemporary stereotypes to mock gently the existentialist set:

Tout le monde se ressemble à peu de choses près; Jamais rasés, cheveux mal taillés, air dépenaillé, C'est vrai! Mais pour nous c'est sacré.

On est crasseux mais on le fait exprès!

Ces philosophes ont pour vivre

Des systèmes merveilleux.

Le seul système qu'ils négligent,

C'est le système pileux.

(...)

Tout le monde danse le vrai be-bop,

Une, deux, trois, hop!

On se télescope,

Ça devient un match de catch.
They all look like each other more or less Unshaven, unkempt hair, altogether scruffy, It's true! But for us it's sacred.

We're filthy, but it's done on purpose!

These philosophers have systems to live their lives That are absolutely marvellous.

The only system they neglect

Is the one to do with hair.

(...)

Everyone dances the real be-bop,

One, two three, hop!

You collide,

It becomes a wrestling match.

The references to collision and wrestling accompany images of be-bop rock $\mathrm{n}$ roll style dancing, while those to hair accompany shots of lookalike young men with long hair and beards, smoking long clay pipes. During the same song, a waiter shouts an order for 'two existentialist halves', and Genès explains to camera that this means 'without a collar', pointing to his own open-necked shirt. Mockery also includes musical forms associated with the existentialist youth culture: earlier in the film we see the musicians playing a be-bop parody during the rehearsal of a more classic bigband number. Poetry, long hair, and be-bop: these are the accoutrements of a generation in revolt, the inheritors of the Zazous and swing music during the early 1940s.

The second example of transition from the old to the new is the films' American references. Just as was the case with the Zazous, revolt is associated with a respect for all things American, which is flagged positively throughout the corpus of films as a culture to be admired and emulated. The orchestra's success is signalled at the end of two films -- Feux de joie and Pigalle-by an American promoter's enthusiasm for the orchestra's performance and an invitation to go to the USA. In other films, it is achieved by the incorporation, sometimes more miss than hit, of American artists, characters or activities. In Mademoiselle s'amuse, for example, the heroine's father is a loud and jokey American businessman, who lets his selfish and strident daughter get away with everything she wants. Her governess reminds us that Christine 'isn't a 100\% American; her poor mother was French, serious, and austere', accentuating the national stereotypes of the film, according to which Americans are impulsive loudmouths, while the French are reasonable and measured. The orchestra finds itself caught between these two extremes. It supports Christine's childish joy in the number 
'Bon appétit Mademoiselle', where each dish of her breakfast is described musically. But it also applies French restraint, when, after a series of outrageous and socially disruptive activities by Christine, the musicians desert her. American stereotypes shade into bad taste in a long masked ball sequence. Christine wants the musicians to be in blackface; her father agrees with the musicians that it is going too far, only to announce that everyone attending should be in blackface. Christine, meanwhile, distracted by the fact that her best friend has stolen her boyfriend, only paints half of her face black (see Figure 2). This emphasizes her half-French half-American nationality, and signals only too well the way in which the film keeps on returning to questions of national identity, as well as underlining the fracture between the 'real' French world and the fantasy of American culture.

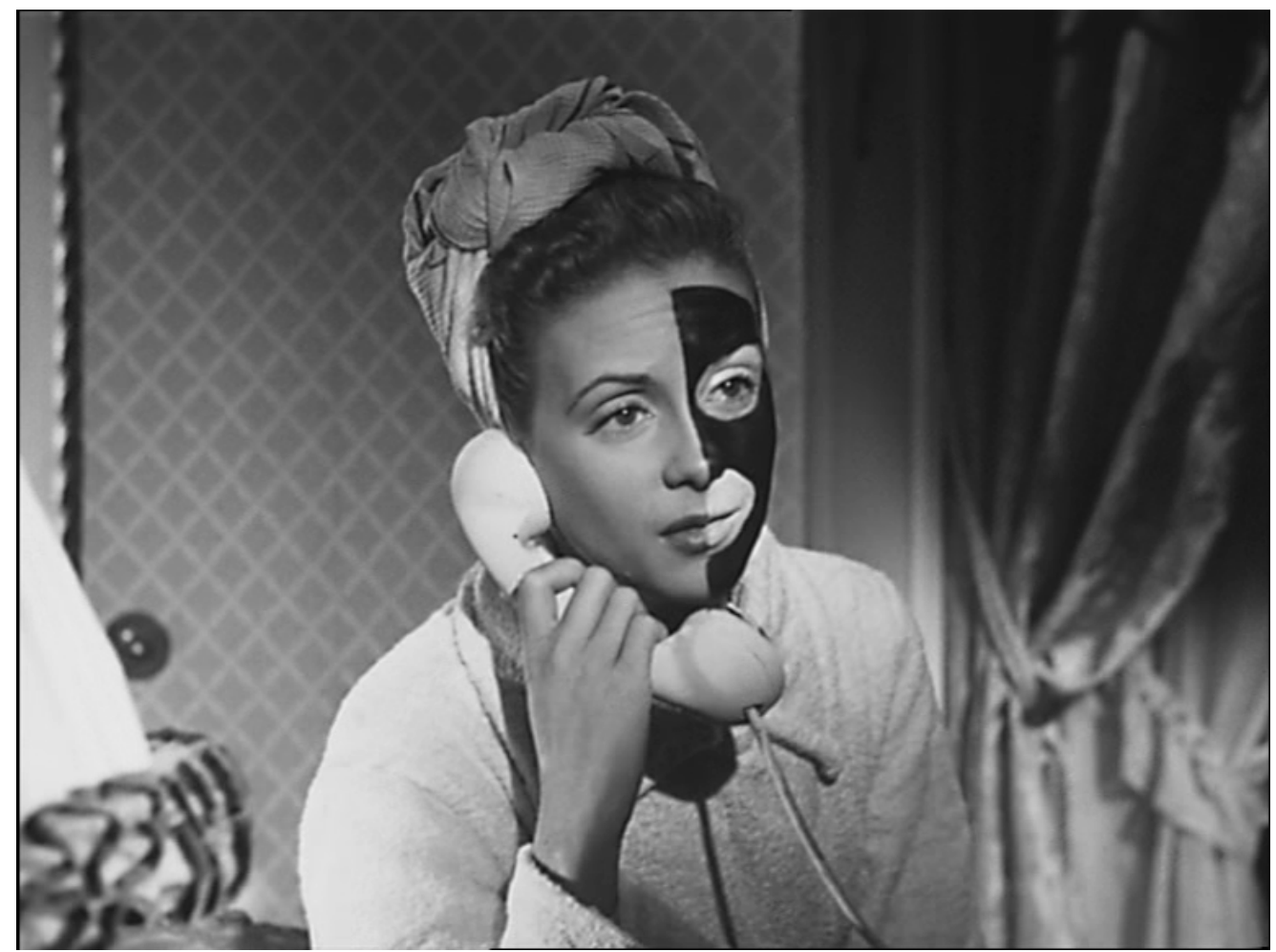

Figure 2: Christine in half blackface in Mademoiselle s'amuse (L.C.J. Editions).

The coming and going between these two worlds is illustrated by a fantasy sequence in Nous irons à Monte-Carlo. Rudy (John Van Dreelen), father of the child at the heart of the plot, invites the orchestra onto his yacht, where they play 'Oui mon amour' (Yes My Love) to him, a song previously heard when Philippe (Philippe Lemaire) sang it to his love, Jacqueline (Danielle Godet). Philippe hallucinates and sees Jacqueline superimposed on Rudy. Rudy, for his part, also hallucinates, and sees his wife Melissa (Audrey Hepburn) superimposed on Philippe, the four characters are campily fused and confused both in terms of nationality and gender.

The third example of transition is the opposition between so-called classical music and swing jazz. In Mademoiselle s'amuse, as was the case for Mademoiselle Swing seven years before, swing music is associated with the USA, and opposed to something more traditional and genteel. The orchestra follows Christine into a tearoom at one point, disrupting the string quartet playing there. There is a more extended and complex opposition of this type in Tourbillon de Paris, in which the orchestra heckles the provincial premiere of an opera by the fictitious Maître Blanche, Brunehaut et Frédégonde, ou les deux reines (Brunehaut and Frédégonde, or the Two 
Queens). It is an ironic reference to the unfinished opera by Ernest Guiraud, Frédégonde, which Camille Saint-Saëns completed and which was performed in 1895. The tenor's aria, 'Un amour sans chagrin' (A Love Without Pain), is performed by Ventura's orchestra later in the film as part of their routine, but the musicians insist that the tenor should sing it with 'more melody, and rhythm', classical music thus being metamorphosed into swing jazz.

In Mademoiselle Swing, the father (Jean Murat) is a classical music composer. His name is Armand de Vincy, a transparent reference to the composer Vincent d'Indy (1851-1931), whom Murat resembles. At the start of the film, we see Murat composing as he sits at his organ. He is interrupted by the swing music that his wife, Sophie (Elvire Popesco), likes to listen to. The two of them then begin a heated discussion, in which 'great music' is contrasted with what he calls 'noise', an opposition already used in Tourbillon de Paris. When we know that D'Indy was principally famous for his Symphonie sur un chant montagnard français (Symphony on a French Mountain Song, 1886), it is perhaps less of a surprise when the Legrand orchestra's first number is a review of the various ways one could get married in the French provinces. We see a wedding from the Auvergne, the musicians wearing traditional Auvergnat costumes and playing wooden instruments; then a Breton wedding, the musicians once again wearing appropriately Breton costumes and playing violins; then a very abrupt change with a swing interlude, followed by the Berri region, but with a swing jazz trio; and, finally, a Poitou wedding, in which swing star Irène (Irène de Trébert) leads the Swing Club of Angoulême in a swing number. The development is neatly managed between classical music contrasted with the oddly assorted pair of swing music and traditional folk music. But the link we might be tempted to make between d'Indy's music and provincial folk music signals the ideological pull of the film towards a middle musical ground. As Sophie says at the end of Mademoiselle Swing, 'there isn't great music or inferior music, there's just music'.

It is of course a commonplace that the film musical constructs the myth of community, where social and class differences disappear in moments of musical jouissance. As Richard Dyer points out, the musical film genre engages in displays of energy to counterbalance social and moral exhaustion, and proposes images of utopian community; in the case of the US musicals he explores, he suggests that this is to counterbalance the fragmentation consequent on the Great Depression of $1929 .{ }^{29}$ For the French musicals explored here, the exhaustion and fragmentation are arguably those consequent on the Second World War. Ventura's trajectory could not be more timely. Before the war, he began with two joyful films (as the title of one of them makes clear: 'feux de joie' means bonfires in French, but literally means 'fires of joy'). Ten years later, Ventura and his orchestra returned from their self-imposed exile in South America. His post-war films recalled the 'good old days' before the war, as evidenced in his pre-war films; the constant repetition of previously published songs, many of them dating from before the war, is crucial in this respect. But at the same time, the films engaged with the new, youthful, post-war France, heading towards rapid industrialisation, Americanization and consumerism, what the French call the 'thirty glorious years' of 1945-1975. Repetition is key for the effect of community to happen. Music and generic situations are repeated. Repetition creates

${ }^{29}$ Richard Dyer, 'Entertainment and Utopia', Movie, no. 24 (1977), pp. 2-13. 
the illusion of a distinctive territory, of a social and musical tissue, Benedict Anderson's 'imagined community'.

Two iconic images of this imagined community occur at the end of Nous irons à Monte-Carlo. Characters separated by generations and nationalities, and separated by the plot revolving around the paternity of the child, are reunited. (French) Philippe holds little Nicolas in his arms on TV as he appeals to the (American) parents to come forward. At the very moment that he sings 'birds of a feather come together', we see the parents, Melissa and Rudy, on the brink of divorce throughout the film, smiling to each other as they recognise their child on the TV screen; and we also see the Philippe's future father-in-law, previously critical of his daughter consorting with a mere singer, finally accepting that he has talent and that he is a worthy suitor for her. The final scene of the film emphasizes even more obviously the notion of community: first, it centres on the child, and therefore on the bright new future; second, the scene brings together husband and wife, father-in-law and son-in-law, American and French in a moment of utopian reconciliation; finally, the last shot is a special effect focusing in almost megalomaniac fashion on Ventura himself, sitting at the piano with his orchestra in miniature on the piano-lid in front of him (see Figure 3). Previously accused, falsely as it turned out, to have fathered the child, Ventura becomes metaphorically the father of both the family represented by the orchestra, and of the extended cross-cultural family associated with it.

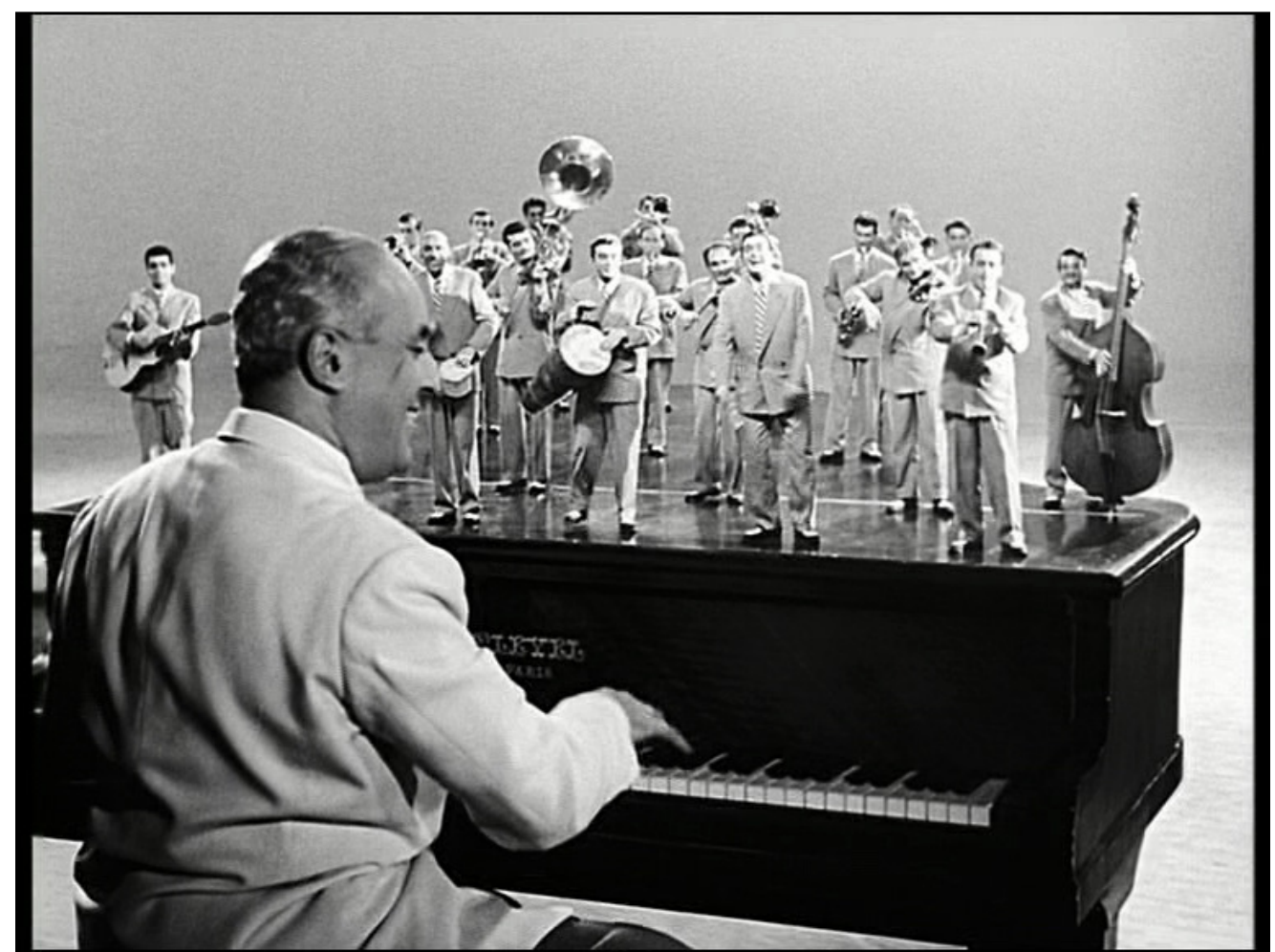

Figure 3: The final shot of Nous irons à Monte-Carlo (René Château Vidéo).

It is worth focusing more tightly on one of Ventura's films, Nous irons à Paris, for a good reason: it was one of the most popular films of its time. When released, it was nineteenth in Paris for both the number of spectators and takings. But in the

\footnotetext{
${ }^{30}$ Benedict Anderson, Imagined Communities: Reflections on the Origin and Spread of Nationalism (London/New York: Verso, 1991).
} 
provinces, it was another story entirely, partly, we can assume, because it tells the story of a group of young musicians conquering that magnet for provincial youth, Paris. Indeed, if the film had so much success, it is no doubt due in part to the fact that, as a contemporary publication pointed out, it was aimed at the youth audience. ${ }^{31}$ The film was in first place in Bordeaux, second in Lille, third in Lyon and Marseille, fourth in Toulouse. It broke all local records in Brest, Nantes, Nice, Périgueux, and Reims; in Grenoble, for example, it earned 3.3 million French francs and had 44,728 spectators in the first seven weeks, representing approximately $40 \%$ of the total population. In Nice, the trade weekly Le Film français (which provides the figures previously quoted), said: 'Remarkably, in its first week of supposedly exclusive screening, this film was in fact screened in three different theatres. Then in the second week, it moved to the Olympia where it earned as much again'. ${ }^{32}$ A special number of the same weekly in 1951 placed the film amongst the top five of 1950 alongside Disney's Cinderella, The Third Man (Carol Reed), Justice est faite/Let Justice Be Done (André Cayatte), and, last but by no means least, The Three Musketeers (George Sidney) with Gene Kelly in the role of D'Artagnan. ${ }^{33}$ The cumulative spectator figures for the period 1950-1999 established by the Centre national de la cinématographie put it in first place for French films in 1950 at 6.7 million, a million of those being in Paris. ${ }^{34}$ When Ventura tried to repeat that success the following year by employing a rising American star, Audrey Hepburn, Nous irons à Monte-Carlo only managed to achieve 3.4 million spectators, and it was only the tenth French film.

The film is exemplary in its deployment of the codes identified above. Where the protagonists are concerned, we find the standard two pairs: the comical father and the comical musician on the one hand, and the romantic couple on the other. The romantic couple is formed by Micheline Grosbois (Francoise Arnoul) and the orchestra's lead singer, Jacques Lambert (Philippe Lemaire). Micheline's father is the choleric Monsieur Grosbois (Fred Pasqali), who is the owner of a business dealing in women's girdles, the brand name being Lotus (see Figure 4). The clandestine radio mocks the product to start with: 'The girdle that crushes the plexus, the girdle that deforms women', and --a play on the homonyms chère (expensive)/chair (flesh)-- 'la gaine la plus chère qui boursoufle les chairs' (the priciest girdle that makes your flesh swell). This naturally arouses Grosbois's anger, but as the free, if negative, publicity leads to higher sales, he designs new lines trading on negative catch lines: 'Plexus endolori' (Sore Plexus), 'Taille meurtrie' (Bruised Waist), and, as he puts it, 'the showpiece of my collection, "Chair boursouflée"” (Swollen Flesh). His daughter joins the orchestra persuading them to change tack, and to support the brand. The radio broadcasts a new and positive tagline: 'Toute femme devient Vénus en portant la gaine Lotus' (Women become Venus with the Lotus girdle). Grosbois is even more incensed, claiming that they are ruining him by praising his girdles. The other comical character is the one associated with the orchestra. In this case it is Honorin, the dimwitted local plod who rapidly joins the ill-assorted radio team; he is played by Max Elloy, whom spectators would have recognized from his roles in Mademoiselle Swing and Mademoiselle s'amuse.

\footnotetext{
${ }^{31}$ Anon., 'Nous irons à Paris', Cinématographie française, no. 1352 (1950), p. 10.

${ }^{32}$ Paul Bublex, 'L'Exploitation', Le Film français, no. 291 (1950), p. 14.

${ }^{33}$ H. Méaulle, 'Etude comparative des recettes d'exclusivité à Paris et dans les villes clés en 1950', Le Film français, nos. 330-331 (1951), p. 51.

${ }^{34}$ Simon Simsi, Ciné-Passions: $7^{e}$ art et industrie de 1945-2000 (Paris: Editions Dixit, 2000), p. 12.
} 


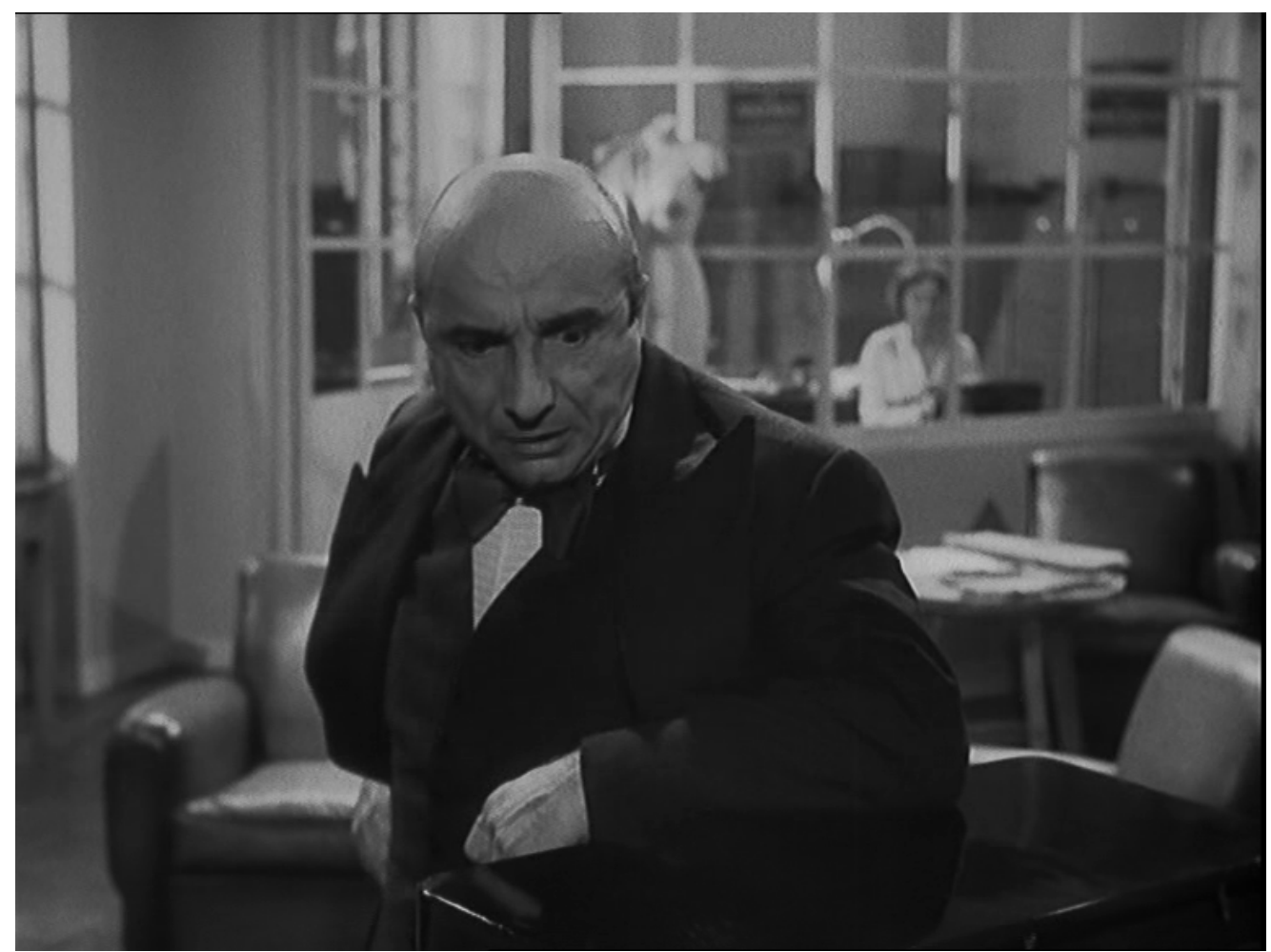

Figure 4: The irate father in Nous irons à Paris (René Château Vidéo).

The focal musical number of the film is a medley mid-way through the film which centres around the main song, 'A la mi-août' (In Mid-August), heard both at the start and at the end of the film as well. Its lyrics play on the sound of a cat mewing ('mi-août' can be pronounced 'miaow' in French). It was pointed out above that musical repetition is essential for this genre. Numbers from previous films are incorporated in the medley, for example, three numbers from Ventura's first important success, Feux de joie, fourteen years before. We learn from the dialogue that the reason for them in this film is that they are the musicians' favourites: there is 'Comme tout le monde', here accompanied by an accordion, unlike Feux de joie, suggesting the traditional music of the guinguette (riverside tavern), 'Sur deux notes' (On Two Notes), and 'Qu'est-ce qu'on attend pour être heureux'. The medley continues with 'Le Chef n'aime pas la musique' (The Boss Doesn't Like Music) from 1939, but which had not appeared in any of Ventura's previous films, before finally arriving at the main song, 'A la mi-août'. There are references in the song both to guinguettes, as well as to a very rural area of France, the Auvergne. 'A la mi-août' segues into a scat performance by the American trio The Peters Sisters (see Figure 5), accompanied by a familiar French face, Henri Salvador, the four of them arriving comically by parachute on the farm where all this is taking place. 


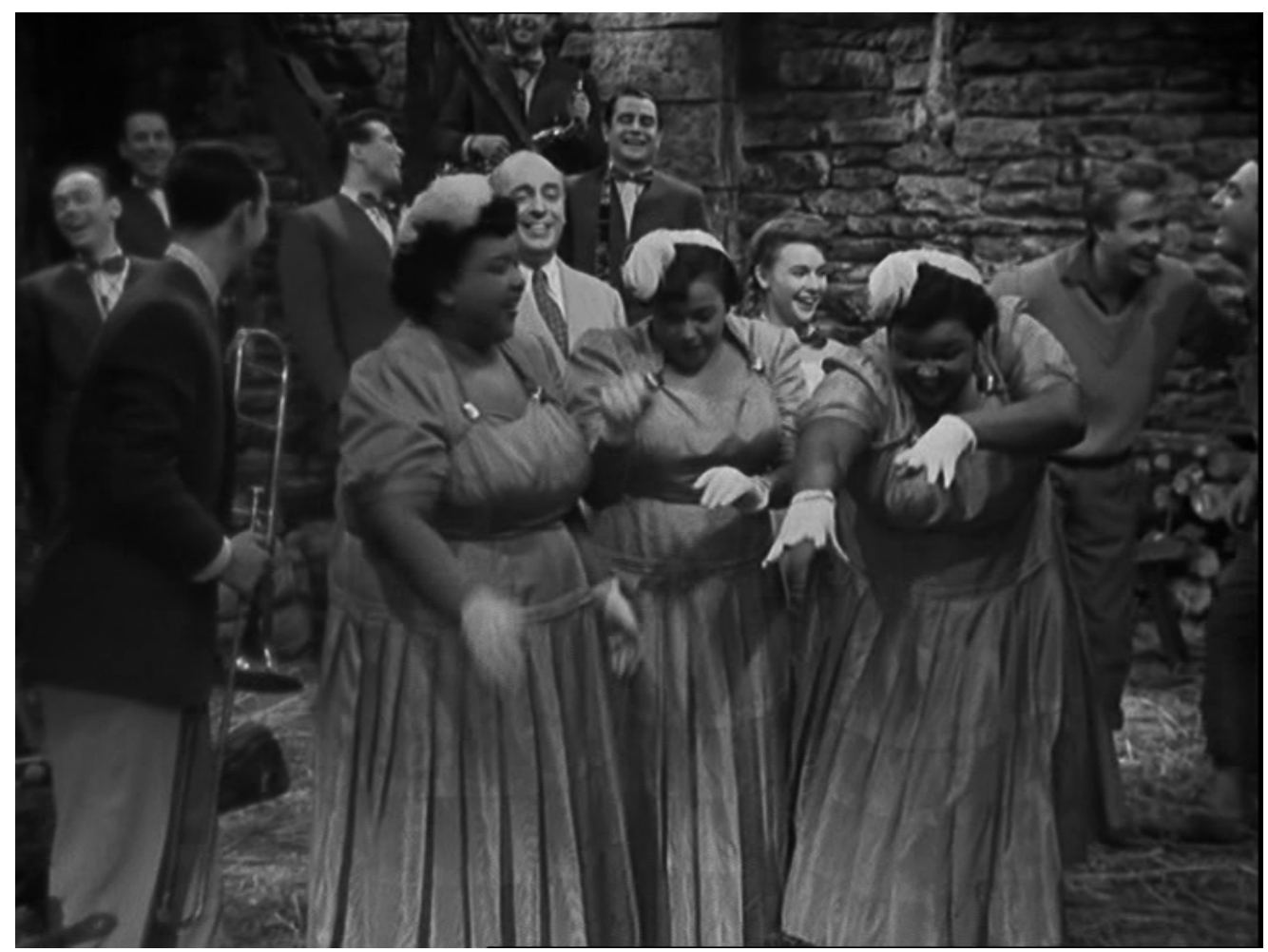

Figure 5: The Peters Sisters in Nous irons à Paris (René Château Vidéo).

The various elements of this medley work to create a distinctive set of meanings for the audience. There is the polarity between the old and the new, which is the defining feature of this sub-genre. Where the 'old' is concerned, there are the references to rural France (the farm, village life), and to traditional music, whether the provincial bourrée, or the more obviously popular music of the guinguettes associated with Paris. Indeed, the references to popular culture are emphasized by the recalling of Ventura's first major film in the song 'Comme tout le monde', with its 1930s style community spirit, the same spirit found in the Popular Front films such as La Belle Équipe/They Were Five (Julien Duvivier, 1936). In other words, a major aspect of the medley is its nostalgic appeal to utopian pre-war sensibilities.

But the medley also gestures to the new in distinctive ways. The central song, 'A la mi-août', conveys the chirpy effervescence of the emerging youth culture, with a refrain that manages to combine the romantic and the suggestively saucy, as well as the energy of youth:

\author{
A la mi-août \\ C'est tell'ment plus romantique \\ A la mi-août \\ Y a d'la joie pour les matous \\ A la mi-août \\ On se sent plus dynamique \\ A la mi-août \\ On s'amuse comme des fous
}

\author{
In mid-August time \\ It's so much more romantic \\ In mid-August time \\ Tomcats get what they want \\ In mid-August time \\ You just feel so much more dynamic \\ In mid-August time \\ Everyone has a ball
}

More importantly, the medley moves from the past to a very American-flavoured present in musical terms. The Peters Sisters' scat is the climax of the medley, closing off a series of allusions to musical numbers rooted in the past, either by their allusions or by the fact that they would have been heard by audiences in Ventura's previous films. Remembering that the plot of the film is about a clandestine radio set up by a 
former Resistance fighter illuminates another aspect of the medley. The fact that The Peters Sisters and Salvador are parachuted into the farm is not just funny; it is also arguably a reference to GIs being parachuted into the French countryside to join forces with the Resistance so as to liberate France from its past. This theme of liberation is taken up by what follows, as the orchestra head towards Paris, pursued by the police across the French countryside; in the last stretch of their journey, they end up travelling on a barge, recalling that other 1930's film with anarchic strands, L'Atalante (Jean Vigo, 1934). But once in Paris, the orchestra triumphs, the media are there to applaud them on the Place de la Concorde (see Figure 6), a key location associated with the Revolution, and its name referring to unity and reconciliation. The echoes are less of the 1930s, and more obviously of the liberation of Paris five years earlier. The freedom promised by the film in this case, however, is a combination of youth culture and freedom of expression, anchored in a Gallic-flavoured American swing music.

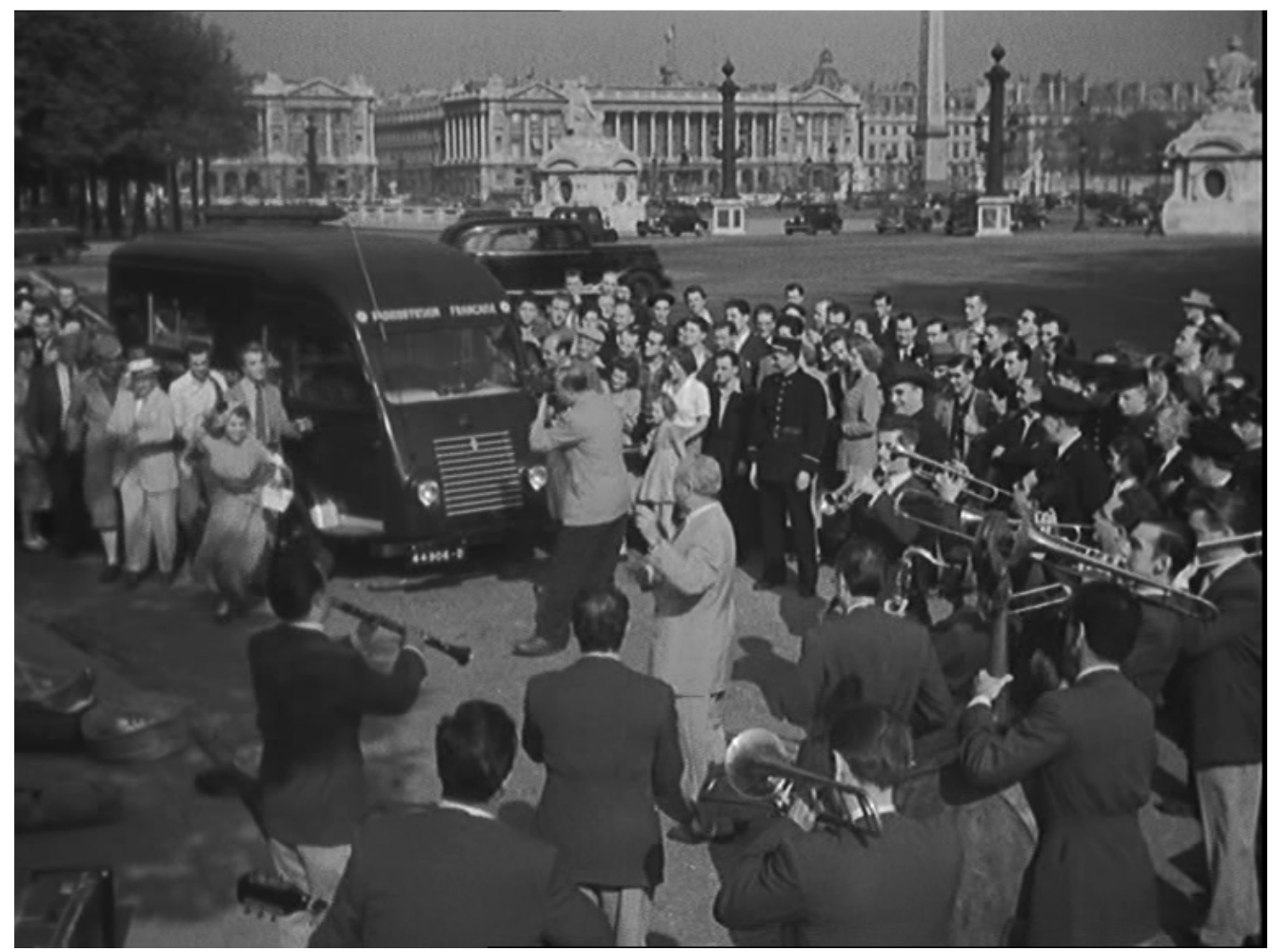

Figure 6: Radio X arrives in triumph in Nous irons à Paris (René Château Vidéo).

While it is true that the musical genre is not as central to French cinema as it is in Hollywood, nonetheless the purpose of this article was to show how it is considerably more significant than might have been thought. A contemporary review of Nous irons à Paris is interesting in this respect. L'Ecran français said of the film that it was 'a laudable attempt to renew the musical comedy genre'. ${ }^{35}$ This comment assumes that the genre had indeed once been more prominent than it was in the 1950s; but, equally, it downplays the success of the film, which, it should be remembered, was the topselling French film of the year. This article has tried to pinpoint some of the reasons

\footnotetext{
${ }^{35}$ Anon., 'Nous irons à Paris: pourquoi pas ?', Ecran français, no. 240 (1950), p. 11.
} 
for its success, and the success of Ventura's previous films, both pre-war and postwar. Ventura's films bridge different musical forms, bridge countries and cultures, in this case France and the USA; bridge the generations, the young represented by the romantic couple and the old, represented by the father; and bridge that familiar tension in French culture, between the rural and the urban. In Feux de joie, the orchestra went to the provinces and stayed there. In Nous irons à Paris, the orchestra goes back to the countryside (see Figure 7) to find its past and characters from the past -the village policeman, the farmer's wife, the resistance fighter-and reconnect with their roots in order to reshape it for the future. But in so doing it also takes the future back into the past: American swing (epitomized by The Peters Sisters), an American star (a cameo by George Raft), and an Americanized French starlet (a cameo by Martine Carol $)^{36}$ into the French countryside. And then, having created a fantasy of community, the orchestra goes back to Paris. The crossover between the past and the future, and between cultures, is neatly characterized by the name of the radio, Radio X; ' $\mathrm{X}$ ' marks the spot where cultures and time cross.

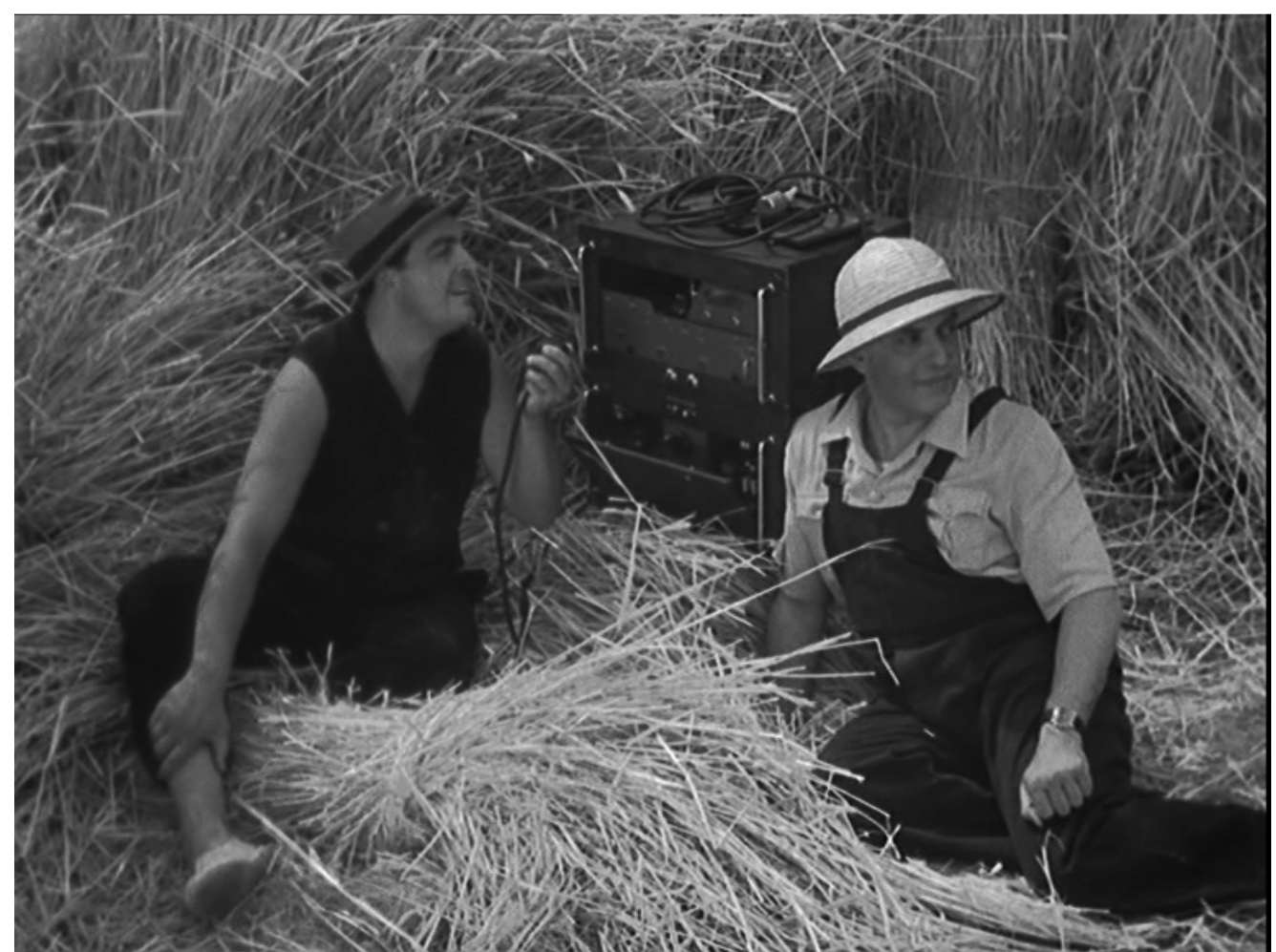

Figure 7: Radio X and its rural roots in Nous irons à Paris (René Château Vidéo).

Arguably, that ' $\mathrm{x}$ ', 1950, midway through the century, was the last time for this kind of relatively uncomplex crossover. The film comes only five years after the war. This was not so far in time that audiences would have forgotten the Resistance and everything that it entailed in social and political terms; and it was also only at the beginnings of the 'thirty glorious years' of industrialisation and Americanisation so

\footnotetext{
${ }^{36}$ Carol had become 'an increasingly American-style vamp' (André-Charles Cohen, Martine chérie (Paris: Ramsay, 1986), p. 38) well before the film that catapulted her to stardom the year after Nous irons à Paris, Caroline chérie (Richard Pottier, 1951). As was pointed out at the time, 'she brings together the art of the American pin up girls and a very French refinement' (Cahiers de la cinéphilie, supplement of Film magazine, quoted in ibid., p. 48).
} 
remorselessly satirised by Jacques Tati a few years later in Mon oncle/My Uncle (1958). Musically, too, this was the optimal moment for a meeting of cultures. Jazz had come to France in the 1920s, and had by the end of the Second World War matured into a distinctively French sound, but with strongly American elements. Ventura bridges the pre-war and the post-war, he incorporates traditional French music-hall, variety, and cabaret styles into his swing sounds.

Ten years later, Hoche Productions tried to renew the successes of the early 1950s with Nous irons à Deauville/We Will Go to Deauville (Francis Rigaud, 1962), this time without Ventura and his orchestra on screen. He was the producer, and the film starred Louis de Funès -the year before the film that made him a top-billing star, Pouic-Pouic (Jean Girault, 1963)--, Michel Serrault, and, as himself, Ventura's nephew, Sacha Distel. The film had barely 2 million spectators. It would therefore be reasonable to say that Nous irons à Paris is the apogee of the pre-Demy musical comedy. A decade after its release, the genre had petered out, to be replaced, if only briefly, by another type of musical, the rock n roll films of the 1960s, or, as they were called in France, the yé-yé films; it is indeed piquant that the film which launched this sub-genre, Johnny Hallyday's D'où viens-tu, Johnny?, was, as mentioned at the start of the article, produced by Ventura. Like their predecessors, these films also deal with a youth class in revolt, but the saxophone was replaced by the electric guitar.

Meanwhile, jazz, whether be-bop or cool, shifted into the soundtracks of the French New Wave. And the fantasy of community inherited from the Popular Front of the 1930s and nourished by post-war redevelopment also deteriorated. It was no longer a question of utopia, but of melancholic noir. Jeanne Moreau, the cynical, but in the end sentimental flower girl of Pigalle-Saint-Germain-des-Prés, becomes Florence in Ascenseur pour l'échafaud/Lift to the Scaffold (Louis Malle, 1958). Ventura's joyful brasses changed into Miles Davis's end-of-the-world muted trumpet. With only a few exceptions, notably the films of Jacques Demy, it would take some 40 years for song to return to the screen in the recent musicals mentioned at the start of this article. 